ted by the various working groups of SCAR, Fifield had the task of producing a readable account of the achievements of Antarctic science, with special reference to the role of SCAR. This could have been no easy task, and one gets the impression that the author experienced more than the usual feeling of relief when the manuscript finally went to the printers. Nevertheless, Fifield has succeeded very well and produced a useful guide to the main fields of Antarctic research.

In places the technical language of the formal report shows through: 'Studies of how plants and animals survive subzero temperatures will continue ...', and there are examples of repetition from one chapter to another which more rigorous editing might have removed. Some of the diagrams could have been improved. They often bear the mark of having been taken off the shelf rather than drawn to illustrate the text. And a list of acronyms would have been invaluable. However, Fifield has topped and tailed the material he received so as to produce a work that hangs together and for the most part reads easily. I found the chapter on the upper atmosphere, never an easy subject, particularly well treated.

The book will be of value to those, specialist and nonspecialist alike, who need a quick update in Antarctic science. It should be required reading for those groups that are newly developing their plans for the research programmes that will qualify their nations for consultative status under the Antarctic Treaty or full membership of SCAR. Many people, particularly those nearer to the hub of Antarctic science, might have wished for a more critical analysis of the way SCAR works, or at times, fails to work. It is one thing to read (p 110) that a working group 'determines priorities for future research', but the crucial question is whether those priorities are followed up. How well is SCAR carrying out its constitutional function of 'furthering the co-ordination of scientific activity in the Antarctic, with a view to framing a scientific programme of circumpolar scope and significance'? Many and significant changes have taken place since the SCAR constitution was drawn up at the Hague in 1958. SCAR delegates, nominated by National Academies, are now less likely to be in a position to commit their nation's resources to a particular scientific programme than they were when the programmes of the IGY were being drawn up. Programme managers, or their equivalents, have a vital role to play in the organisation of programmes and the commitment of logistic resources to them. The conflicting styles of institute-based research and programmes arising from peer-reviewed grant applications have to be reconciled.

Richard Fifield's book does not set out to discuss these points, though it recognises their existence. What it does set out to do, to present to the public the results of scientific research in the Antarctic, it does very well, and SCAR and the Antarctic community generally, has reason to be grateful to Fifield. (W. Nigel Bonner, British Antarctic
Survey, High Cross, Madingley Road, Cambridge CB3 OET.)

\section{BRIEF REVIEWS}

HUNTERS, PASTORALISTS AND RANCHERS. Ingold, T. 1988. Cambridge, Cambridge University Press. $326 \mathrm{p}$, illustrated, soft cover. ISBN 0521358876 . $£ 10.95$; US $\$ 15.95$.

Subtitled 'Reindeer economies and their transformations'; the paperback edition of a book which first appeared in 1980 (reviewed in Polar Record 20 (127): 378-9 (1981), with a rebuttal from the author in the following issue, p 457). The original reviewer, Ian Whitaker, now writes 'Although I do not agree with all his argument, it is good to see this thought-provoking monograph available to a wider readership. Ingold's experience of reindeer management, springing from his fieldwork among the Skolt Lapps (Sami) of northern Finland, gives the book many insights from the field, to supplement his data derived from the library'

THE SOVIET MARITIME ARCTIC. Brigham, L. W. and Gately, E. M. (editors). 1988. Woods Hole Oceanographic Institution Technical Report WHOI-88-5. 67 p, illustrated, soft cover.

A summary of an international workshop held May 10-13 1987 by the Marine Policy Center of Woods Hole, involving 28 participants from Canada, Britain, Norway and the US. The meetings provided '... a forum for Western scholars to examine and discuss Soviet domestic international policies regarding the Arctic Ocean' and addressed ... 'strategic, geographic, historical, legal, scientific, technological, transportation, geopolitical and resource development' concerns. The report includes abstracts of 15 contributed papers and an edited transcript of the concluding discussion; report abstracts are in English and Russian.

STUDENT RESEARCH IN CANADA'S NORTH. Adams, W.P. and Johnson, P. G. (editors). 1988. Ottawa, Association of Canadian Universities for Northern Studies. 596 p, illustrated, soft cover. ISBN 0-921421-02-8. Can $\$ 25.00$ in Canada, Can $\$ 35.00$ including postage elsewhere, Can $\$ 10.00$ for students.

These proceedings, covering the first National Student Conference on Northern Studies, held in Ottawa in November 1986, ‘... represent the first comprehensive record of the level and nature of student activity in Northern Studies in Canada's universities today'. The wholly admirable objective of the conference was that the 'next generation' of Northern scholars should get to know each other, become familiar with each others's work, and be sensitive to the multidisciplinary context of their research. There are 101 papers, many of very high standard, grouped under Physical Sciences, Life Sciences and Human Sciences, with abstracts in English and French. 